\title{
E-TOLL COLLECTION PADA SISTEM TRANSAKSI TOL TERTUTUP DENGAN METODE LAYANAN BERBASIS LOKASI STUDI KASUS PT JASA MARGA (PERSERO), TBK
}

\author{
Rahmat Nur Isni ${ }^{(1)}$, Budi Santosa(2), Oliver Samuel Simanjuntak ${ }^{(3)}$ \\ Jurusan Teknik Informatika Fakultas Teknik Industri UPN "Veteran" Yogyakarta \\ Jl. Babarsari 2 Tambakbayan Yogyakarta \\ email: rahmatisni@gmail.com ${ }^{(1)}$, dissan@upnyk.ac.id (2), oliver.simanjuntak@upnyk.ac.id(3)
}

\begin{abstract}
Jasa Marga (Persero) Tbk is an Indonesian State-Owned Enterprise engaged in toll road service providers. Some of the problems that arise in toll transaction and payment services, which are transaction services on closed toll systems that cannot fulfill payment systems without tapless method, e-money transaction system problems, queue problems, and paper waste problems. E-Toll Collection is an application consist of toll transaction and payment applications using a server-based digital account that can read the location of gates and transaction substations on open toll systems and closed toll systems. The method used in searching transaction locations uses trilateration by using the RSSI value to be the distance (meter) between the location points of access points with the user. Based on the tests in Cikarang Utara Toll Gate, the results of the coordinates of the gate and substation readings were obtained with an average of $92.7 \%$ with \pm 1 -meter errors, the results of response time on open and closed toll system transactions with an average of 2 seconds.
\end{abstract}

Keywords : Digital Payment, E-Toll Collection, Location Based Service, RSSI Ranging, Trilateration, Wifi Positioning System

\begin{abstract}
Abstrak
Jasa Marga (Persero) Tbk adalah Badan Usaha Milik Negara Indonesia yang bergerak dibidang penyelenggara jasa jalan tol. Beberapa permasalahan yang kerap muncul pada pelayanan transaksi dan pembayaran tol, diantaranya adalah pelayanan transaksi pada sistem tol tertutup yang belum bisa melayani sistem pembayaran secara tapless, masalah sistem transaksi uang elektronik, masalah antrian dan masalah polusi berupa limbah kertas dan polusi udara. E-Toll Collection merupakan aplikasi transaksi dan pembayaran tol menggunakan rekening digital berbasis server yang dapat membaca lokasi gerbang dan gardu transaksi pada sistem tol terbuka dan sistem tol tertutup. Metode yang digunakan dalam pencarian lokasi transaksi adalah trilateration dengan menggunakan nilai RSSI yang dikonversi menjadi jarak (meter) antara titik lokasi akses poin dengan user.Berdasarkan pengujian yang dilakukan pada gerbang tol Cikarang Utara, diperoleh hasil akurasi koordinat pembacaan lokasi gerbang dan gardu dengan rata-rata $92,7 \%$ dengan toleransi kesalahan sebear \pm 1 meter, hasil response time pada transaksi sistem tol terbuka dan tertutup diselesaikan dengan rata-rata 2 detik.
\end{abstract}

Kata kunci: Digital Payment, E-Toll Collection, Location Based Service, RSSI Ranging, Trilateration, Wifi Positioning System

\section{PENDAHULUAN}

Jalan Tol adalah jalan umum yang kepada para pemakainya dikenakan kewajiban membayar tol. Tol adalah sejumlah uang tertentu yang dibayarkan untuk pemakaian Jalan Tol (Badan Pemeriksa Keuangan Republik Indonesia, 2018). Electronic toll collection adalah sebuah teknologi untuk mengumpulkan pembayaran tol. Electronic toll collection bertujuan untuk mengurangi kemacetan dan mempercepat proses pembayaran tol (Dhurat, Magal, Chheda, \& Ingle, 2014). Dalam sistem transaksi electronic toll collection, pihak badan usaha jalan tol dan pihak bank menyediakan alat transaksi yang disebut mesin GTO (gardu tol otomatis). Mesin 
gardu tol otomatis berfungsi melakukan autentifikasi dan transaksi data E-Toll card sesuai dengan tarif yang berlaku.

Dalam transaksi electronic toll collection, terdapat dua metode transaksi pembayaran tol yang diaplikasikan PT Jasa Marga (Persero), Tbk, yaitu dengan metode sistem transaksi E-Toll card (Gardu Tol Otomatis) dan e-Toll pass. Metode pembayaran E-Toll card adalah pembayaran tol secara tapping. Tapping adalah proses menempelkan E-Toll card pada reader yang terdapat pada gardu tol otomatis. Setelah tahapan tapping dilakukan, data diproses mesin menuju sistem transaksi. Metode pembayaran e-Toll pass adalah pembayaran tol yang dilakukan dengan teknologi nirsentuh. Sistem e-Toll pass menggunakan transcevier OBU (On Board Unit).

OBU (On Board Unit) adalah alat yang terpasang pada kendaraan (Fatkhurrahman, Syafei, \& Darjat, 2017). OBU (On Board Unit) berfungsi untuk membaca tag pasif RFID yang membawa nomor identitas kendaraan dan mengirimkan identitas ini ke OBU Reader saat memasuki gerbang tol. OBU Reader merupakan alat yang terpasang pada gerbang tol, berfungsi untuk mendeteksi setiap kendaraan yang terpasang OBU yang memasuki gerbang tol dan mengirim data ke blok pemroses dan penyimpanan data.

Pada sistem transaksi e-toll pass dengan menggunakan OBU (On Board Unit) terdapat kendala yang dihadapi oleh operator jalan tol, yaitu pada gerbang tol dengan sistem transaksi tertutup. Pada sistem transaksi tertutup, OBU (On Board Unit) tidak dapat menyimpan data asal gerbang masuk kendaraan pada saat awal proses transaksi. Kendala tersebut berdampak pada operator jalan tol yang belum dapat mengaplikasikan pembayaran pada sistem tol tertutup dengan e-toll pass.

Sistem pengumpulan tol tertutup adalah sistem pengumpulan tol yang penggunanya diwajibkan mengambil tanda masuk pada gerbang masuk dan membayar tol pada gerbang keluar. Berdasarkan data perusahaan, gerbang tol pada ruas jalan tol Jakarta-Cikampek yang belum dapat melakukan transaksi menggunakan OBU (On Board Unit) diantaranya, gerbang tol Cikunir 1, Cikunir 3, Cikarang Utama, Cikarang Barat 2, Cibatu, Cikarang Timur, Karawang Barat 1, Karawang Barat 2, Karawang Timur 1, Karawang Timur 2, Kalihurip 1, Kalihurip 2, Dan Cikampek (Jasa Marga, 2018).

OBU (On Board Unit) memiliki faktor risiko lainnya, diantaranya adalah limbah kertas dan antrian kendaraan pada gerbang tol. OBU (On Board Unit) belum bisa melakukan monitoring transaksi pembayaran tol. Perusahaan saat ini masih menggunakan struk tol sebagai bukti pembayaran pada transaksi tol. Struk yang tidak diambil ataupun sudah tidak terpakai kemudian menjadi limbah kertas dan mencemari lingkungan gerbang tol. Selain itu OBU (On Board Unit) tidak dapat melakukan top up dan membagikan saldo secara mobile. Hal tersebut berpotensi menimbulkan antrian pada gerbang tol ketika arus lalu lintas sedang padat. Antrian disebabkan oleh pengguna tol yang memberhentikan kendaraannya pada gardu tol ketika saldo tidak mencukupi. Pengguna tol diwajibkan untuk menekan tombol bantuan dan membeli kartu dengan saldo baru secara tunai.

Pada penelitian ini akan dibangun Aplikasi E-toll Collection dengan Metode Layanan Berbasis Lokasi PT Jasa Marga (Persero), Tbk. Aplikasi ini dibangun sebagai alternatif dari sistem pembayaran tol meggunakan OBU (On Board Unit) menjadi teknologi smartphone yang memungkinkan untuk melakukan pembayaran tol pada sistem transaksi tertutup. Aplikasi akan dibangun menggunakan sistem rekening digital berbasis server untuk melakukan transaksi pembayaran tol. Posisi transaksi gardu tol dibutuhkan sistem agar dapat terintegrasi dengan sistem palang gardu tol. Teknologi wifi pada smartphone digunakan dalam melakukan scanning terhadap akses poin berdasarkan mac adress untuk membaca gerbang tol. Pembacaan posisi gardu transaksi menggunakan metode RSSI-Based yaitu berdasarkan nilai kuat sinyal (dBm) dan penentuan lokasi dari tiga akses poin dengan metode trilateration yang membentuk sebuah persamaan jarak dan metode untuk menentukan posisi gardu. Selanjutnnya aplikasi akan masuk ke sistem pembayaran tol sebagai user untuk diproses dalam sistem transaksi tol. Penelitian ini dibangun menggunakan pemrograman android sebagai pendukung sarana pelayanan transaksi E-toll Collection dengan menampilkan aktivitas transaksi kepada pengguna tol. 


\section{Metodologi Penelitian}

\subsection{Metodologi Pengembangan Sistem}

Metodologi pengembangan sistem yang digunakan adalah dengan metode Guidelines for Rapid APPlication Engineering (GRAPPLE). Menurut (Schmuller, 2004) mengemukakan bahwa metode GRAPPLE merupakan metode pengembangan sistem yang setiap tahapannya terdiri dari beberapa tindakan, dan setiap tindakannya menghasilkan produk berupa UML. Adapun tahapan yang digunakan dalam metode (Yuliawan, Sakti, Priyandari, \& Hisjam, 2016):

1. Requirement Gathering

Pembahasan mengenai kebutuhan apa saja yang akan dibutuhkan dalam perancangan sistem tersebut. Termasuk kebutuhan perangkat lunak maupun perangkat keras yang dibutuhkan.

2. Analysis

Mengurai permasalahan melalui informasi yang telah didapatkan selama identifikasi kebutuhan sistem.

3. Design

Hasil dari analisis yang diungkapkan dalam bentuk solusi perancangan, yakni dengan merancangan user interface. Dengan demikian menilai apakah pengembangan sistem sesuai dengan spesifikasi atau tidak.

4. Development

Pada bagian ini programmer mengambil alih kendali pengembangan sistem melalui pengkodean berdasarkan diagram yang telah dirancang pada tahapan sebelumnya. Kemudian hasil pengkodean sistem diintegrasikan dengan user interface yang telah dibuat, selanjutnya dilakukan pengetesan melalui pengujian komparasi yang telah dirancang sebelumnya.

\subsection{Arsitektur Sistem}

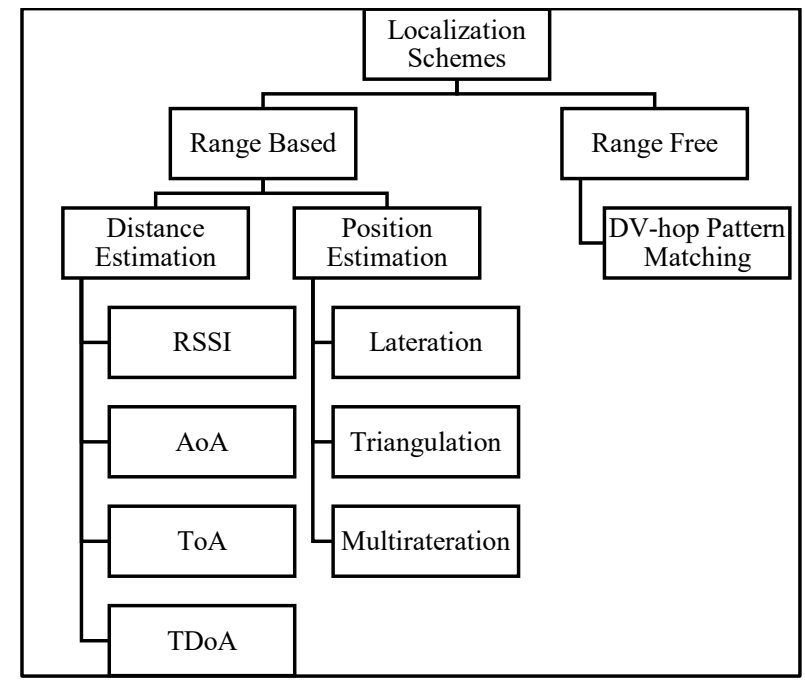

Gambar 1. Skema Metode Layanan Bebasis Lokasi

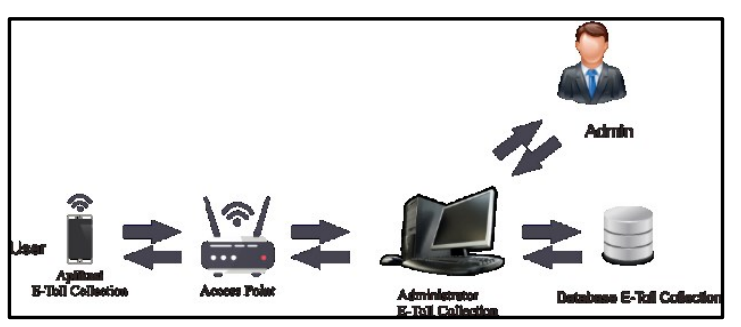

Gambar 2. Arsitektur Aplikasi E-Toll Collection 


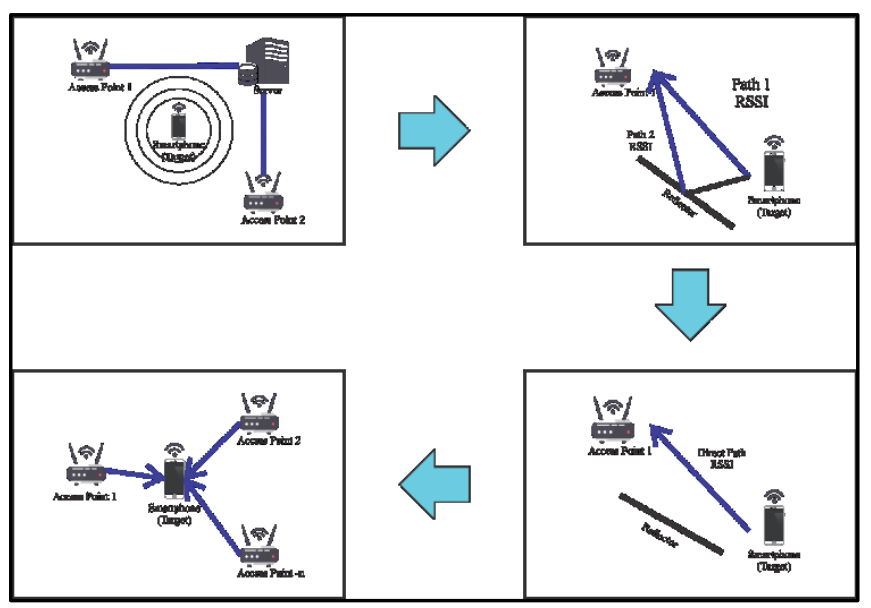

Gambar 3. Arsitektur Sistem Layanan Berbasis Lokasi

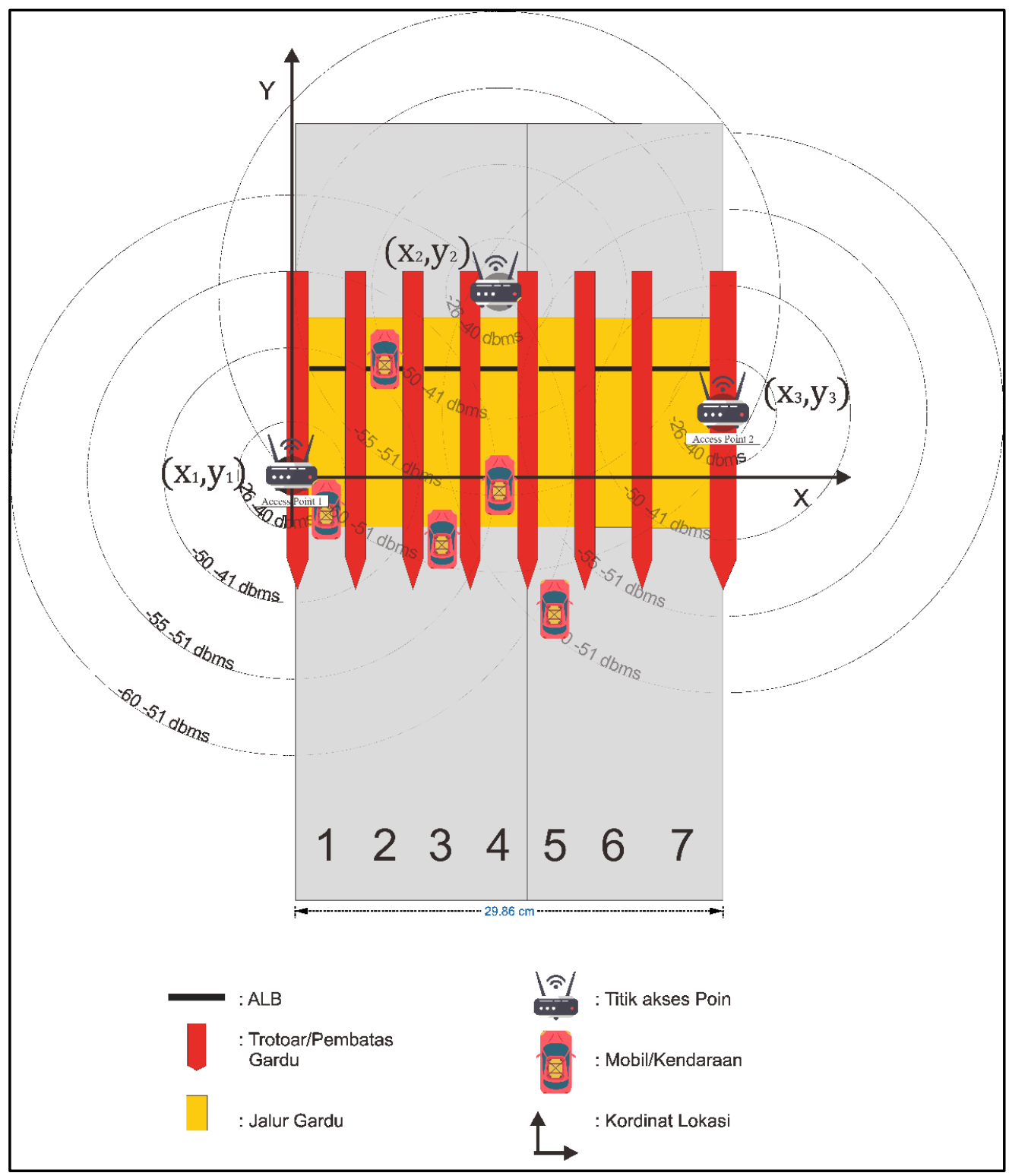

Gambar 4. Skema Sistem Transaksi Tol Elektronik dengan Mac adress 


\subsection{Spesifikasi Alat}

\begin{tabular}{|l|l|}
\hline \multirow{5}{*}{ General } & Brand: XiaoMi \\
& Model: Mi Router 3 \\
& Color: White \\
& Type: Wireless Router \\
Interface: LAN,USB2.0,WAN & Gain dBi: $5 \mathrm{dBi}, 6 \mathrm{dBi}$ \\
& Transmission Rate: $1167 \mathrm{Mbps}$ \\
& Quantity of Antenna: 4 \\
& WIFI Transmission Protocol: 802.11b/n/g,802.3/3U,IEEE 802.11ac \\
& Wireless Security: WPA-PSK,WPA2-PSK \\
& Support System: Android,IOS,Mac OS,Windows 2000,Windows 7,Windows 8,Windows \\
& 8.1,Windows 98,Windows 98SE,Windows ME,Windows Vista,Windows XP \\
\hline
\end{tabular}

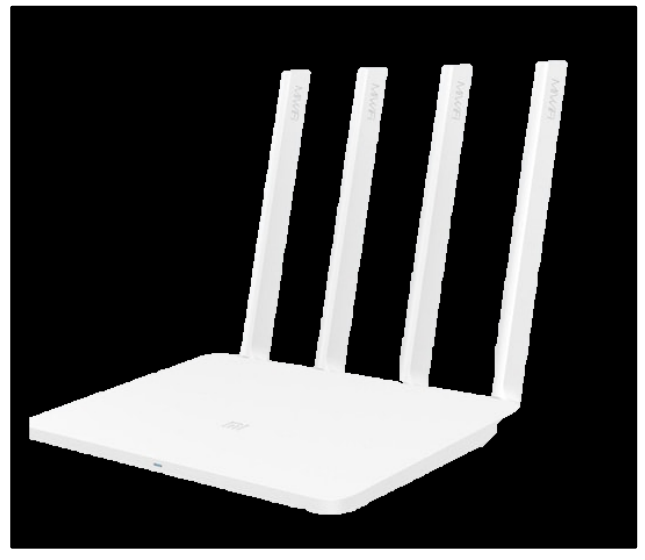

Gambar 5 Xiaomi Router 3 dan Spesifikasinya

\subsection{Perancangan Proses}

Perancangan proses berupa pembuatan UML yang menggambarkan bagaimana langkahlangkah proses pembuatan aplikasi E-Toll Collection. Proses pembuatan UML tediri dari use case diagram, activity diagram, sequence diagram, class diagram.

\section{Use Case Diagram Member}

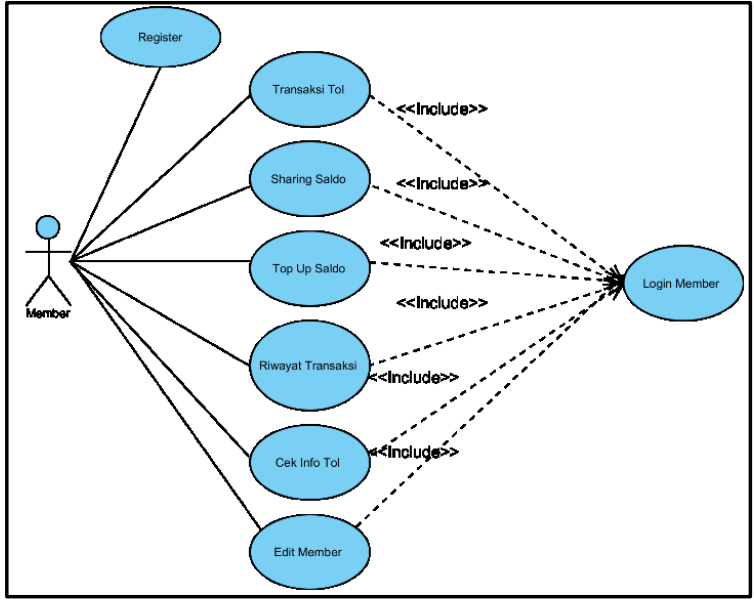

Gambar 7. Use Case Diagram Member 


\section{Use Case Diagram Admin}

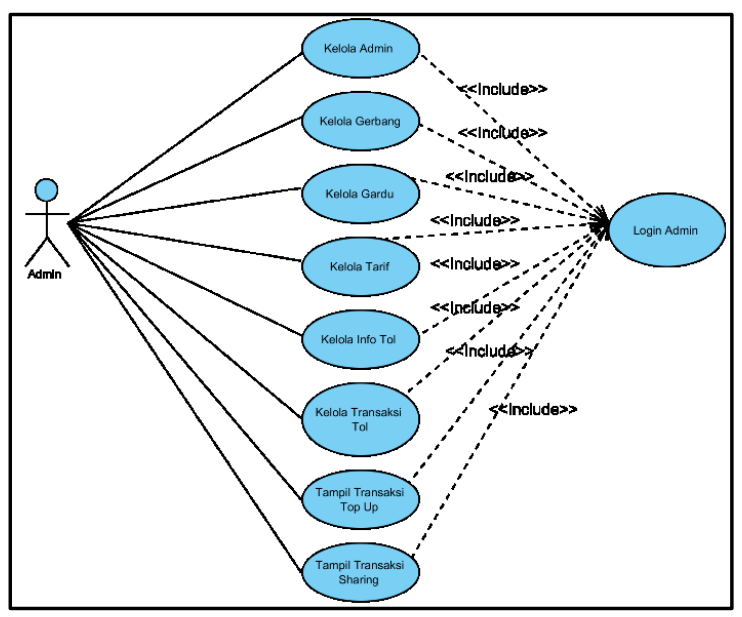

Gambar 7. Use Case Diagram Admin

\section{Activity Diagram}

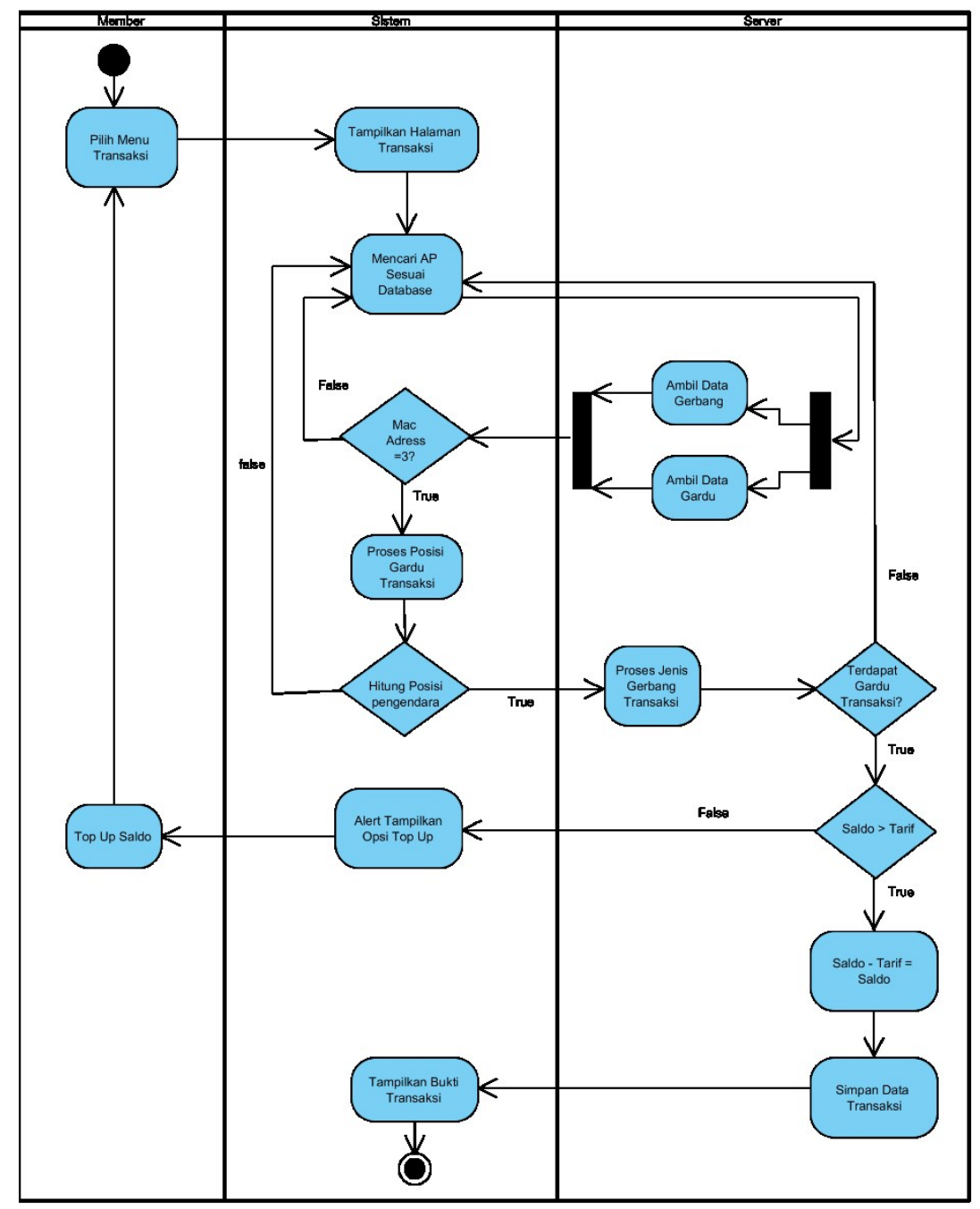

Gambar 9. Activity Diagram Transaksi Tol 


\section{Class Diagram}

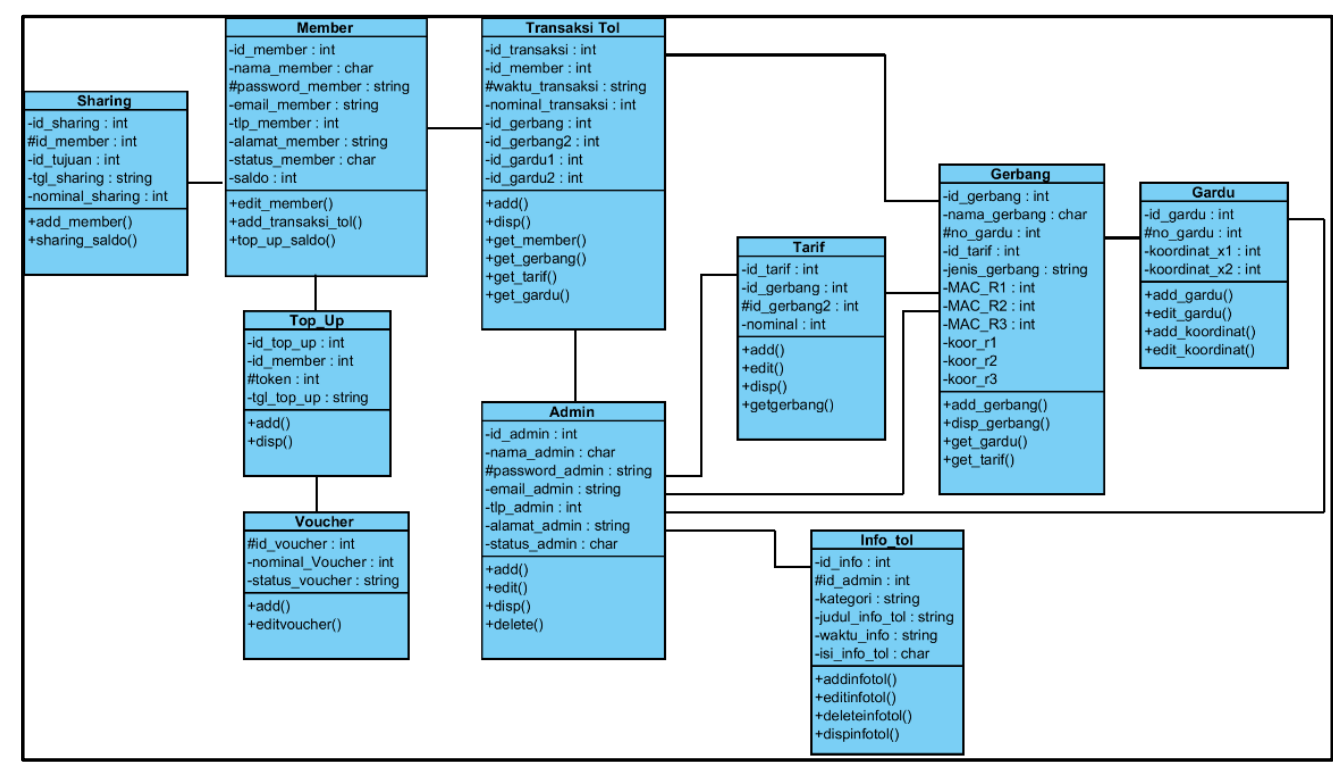

Gambar 10. Class Diagram E-Toll Collection

\section{Sequence Diagram Transaksi Tol}

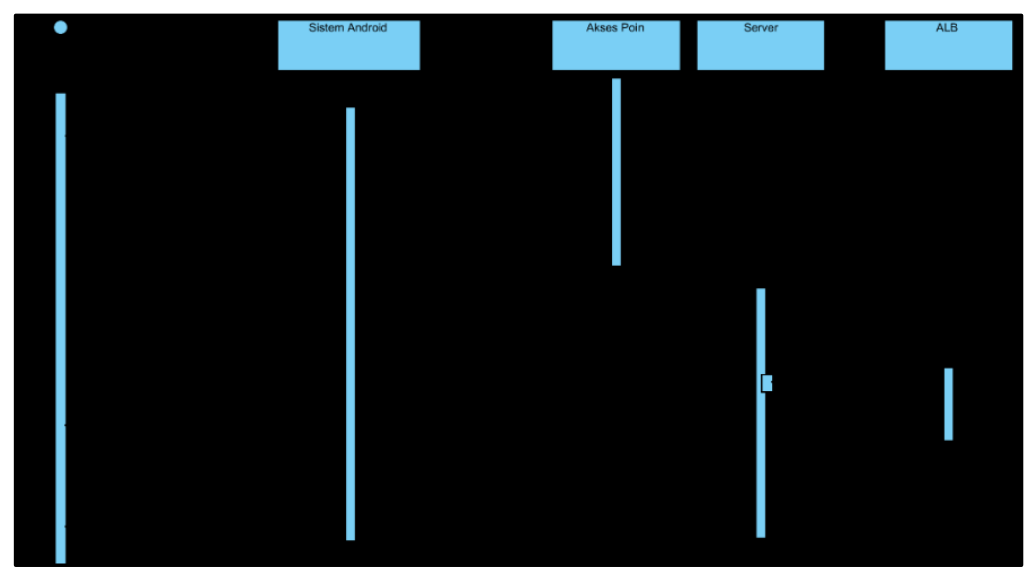

Gambar 11. Class Diagram E-Toll Collection

\section{HASIL DAN PEMBAHASAN}

Hasil dari pembahasan akan menjelaskan penerapan penggunaa metode RSSI Ranging dan Trilateration, hasil pengujian sistem terdiri dari uji koordinat, response time dan black box di daerah Cikarang Utara, ruas tol Jakarta-Cikampek.

\subsection{Location based on service}

LBS (Location-Based on Services) adalah layanan informasi dan teknologi yang menyediakan informasi yang sudah dibuat, disusun, dipilih atau diseleksi menuju perhitungan lokasi terbaru dari pengguna atau orang lain atau objek bergerak (Kupper, 2005). Penggunaan teknologi LBS (Location-Based Services) saat ini sudah menjadi teknologi yang umum digunakan dalam penggunaan aplikasi mobile, seperti penerapan posisi lokasi pada sistem navigation google maps, fitur location pada sosial media, aplikasi game yang memanfaatkan penggunaan GPS 
(Global Positioning System) dan aplikasi pelacak smartphone. Terdapat empat komponen pendukung utama dalam teknologi layanan berbasis lokasi, yaitu: piranti mobile, jaringan komunikasi, komponen positioning penunjuk posisi, dan penyedia layanan (Anwar, Jaya, \& Kusuma, 2014).

\subsection{Log Normal Shadowing Model dan FSPL}

Log-normal shadow model adalah model yang saat ini banyak dikembangkan dimana memiliki parameter yang dapat dikonfigurasi dan cukup stabil untuk digunakan pada situasi lingkungan indoor maupun outdoor.

$$
L=10(n) \log _{10}(d)+C
$$

Tabel 1. Tabel nilai Path Loss Exponent

\begin{tabular}{|c|c|}
\hline Environment & Path Loss Exponent \\
\hline Free Space & 2 \\
\hline Urban Area Cellular Radio & 2.7 \\
\hline Shadowed Urban Cellular Radio & 3 to 5 \\
\hline In Building line of site & 1.6 to.8 \\
\hline Obstructed in Building & 4 to 6 \\
\hline Obstructed in Factory & 2 to 3 \\
\hline
\end{tabular}

Dalam pembelajaran wireless communication, nilai jarak real yang didapat dari perhitungan menggunakan log normal shadowing model dapat dioptimasi menggunakan model free space path loss untuk mengurangi tingkat grain pada jalur komunikasi dengan melibatkan spesifikasi dari frequensi jaringan yang digunakan yaitu 2.4 Ghz dalam satuan dB.

Berikut adalah rumus sederhana y untuk mengkonversi path loss menjadi satuan jarak real dalam satuan meter.

$$
F S P L(d B)=10(n) \log _{10}(d)+20 \log _{10}(f)-C
$$

Distance $(d)$ adalah jarak antara transmiter dan receiver dalam satuan meter. Nilai $(d)$ didapat berdasarkan pengukuran jarak antara transmiter dan receiver. Environment constant (C) adalah nilai kekuatan sinyal terbaik yang dapat ditangkap oleh receiver berdasarkan pengukuran pada jarak satu meter. Frequency $(f)$ adalah ukuran jumlah putar ulang dalam satuan detik dengan satuan $\mathrm{Hz}$.

\subsection{Trilateration}

Trilateration atau metode trilaterasi merupakan sebuah metode pencarian koordinat sebuah titik berdasarkan referensi jarak titik tersebut pada 3 buah koordinat yang sudah diketahui (Mistry \& Mistry, 2015). 


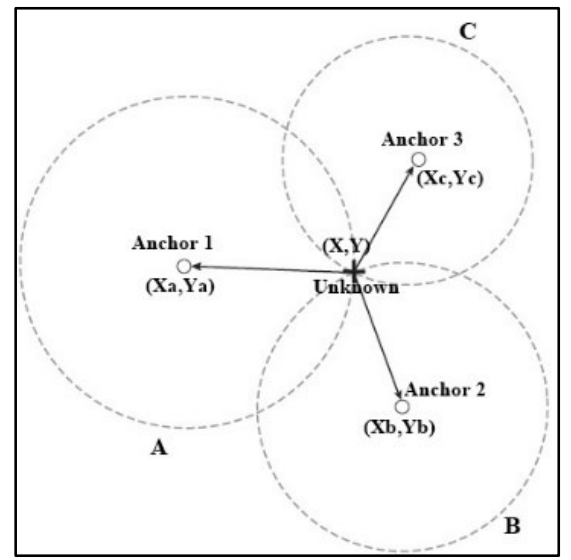

Gambar 12. Skema Lokaslisasi dengan Trilaterasi

Dimana kuadrat jarak antara unknown node dan anchor node $i$ dapat dinyatakan melalui rumus di bawah ini:

$$
d_{i}^{2}=\left(x-x_{i}\right)^{2}+\left(y-y_{i}\right)^{2}
$$

Pada rumus di atas diketahui bawha $i=1$ sebagai titik acuan, di mana $x_{1}=y_{1}=0$, dengan demikian untuk $i>1$ persamaannya dapat ditulis sebagai:

$$
r_{i}^{2}-r_{1}^{2}=x_{i}^{2}-2 x x_{i}+y_{i}^{2}-2 y y_{i}
$$

Unknown node adalah nilai yang mewakili koordinat dari titik posisi member $(x, y)$. Nilai anchor node adalah nilai yang mewakili koordinat dari titik posisi router yang sudah diketahui sebelumnya $\left(x_{i}, y_{i}\right)$. Selanjutnya proses pencarian nilai unknown node didapatkan melalui persamaan dari perhitungan rumus kuadrat jarak antara unknown node dan anchor node. Dimana kuadrat jarak antara unknown node dan anchor node dapat dinyatakan melalui perhitungan $\mathrm{x}$, y. Rumus trilateration dimulai dengan 3 persamaan lingkaran yaitu dapat dilihat pada persamaan 2.1, 2.2 dan 2.3.

$$
\begin{aligned}
& r_{1}^{2}=\left(x-x_{1}\right)^{2}+\left(y-y_{1}\right)^{2} \\
& r_{2}{ }^{2}=\left(x-x_{2}\right)^{2}+\left(y-y_{2}\right)^{2} \\
& r_{3}{ }^{2}=\left(x-x_{3}\right)^{2}+\left(y-y_{3}\right)^{2}
\end{aligned}
$$

Dari persamaan di atas dapat dijabarkan menjadi persamaan 2.4, 2.5 dan 2.6.

$$
\begin{aligned}
& x^{2}-2 x_{1} x+x_{1}{ }^{2}+y^{2}-2 y_{1} y+y_{1}{ }^{2}=r_{1}{ }^{2} \\
& x^{2}-2 x_{2} x+x_{2}{ }^{2}+y^{2}-2 y_{2} y+y_{2}{ }^{2}=r_{2}{ }^{2} \\
& x^{2}-2 x_{3} x+x_{3}{ }^{2}+y^{2}-2 y_{3} y+y_{3}{ }^{2}=r_{3}{ }^{2}
\end{aligned}
$$

Jika persamaan 2.5 dikurangi dengan persamaan 2.4, maka akan menghasilkan persamaan 2.7.

$$
\left(-2 x_{1}+2 x_{2}\right) x+\left(-2 y_{1}+2 y_{2}\right) y=r_{1}{ }^{2}-r_{2}{ }^{2}-x_{1}{ }^{2}+x_{2}{ }^{2}-y_{1}{ }^{2}+y_{2}{ }^{2}
$$

Jika persamaan 2.6 dikurangi dengan persamaan 2.5, maka akan menghasilkan persamaan 2.8.

$$
\left(-2 x_{2}+2 x_{3}\right) x+\left(-2 y_{2}+2 y_{3}\right) y={r_{2}}^{2}-{r_{3}}^{2}-x_{2}{ }^{2}+x_{3}{ }^{2}-y_{2}{ }^{2}+y_{3}{ }^{2}
$$

Dalam bentuk matriks dengan $\mathrm{i}=1$ sampai 3 , dilakukan pengurangan dari bentuk persamaan $r_{1}$ terhadap $r_{2}$ dan $r_{2}$ terhadap $r_{3}$ persamaan dapat ditulis sebagai : 


$$
\left[\begin{array}{l}
\left(2 x_{2}-2 x_{1}\right)\left(2 y_{2}-2 y_{1}\right) \\
\left(2 x_{2}-2 x_{3}\right)\left(2 y_{2}-2 y_{3}\right)
\end{array}\right]\left[\begin{array}{l}
x \\
y
\end{array}\right]=\left[\begin{array}{l}
x_{2}{ }^{2}-x_{1}{ }^{2}+y_{2}^{2}-y_{1}^{2}+r_{1}^{2}-r_{2}^{2} \\
x_{2}^{2}-x_{3}^{2}+y_{2}^{2}-y_{3}^{2}+r_{3}^{2}-r_{2}^{2}
\end{array}\right]
$$

Maka didapatkan dua persamaan sebagai berikut, yaitu :

$$
\begin{gathered}
{\left[\begin{array}{ll}
A x & B y \\
D x & E y
\end{array}\right]=\left[\begin{array}{l}
C \\
F
\end{array}\right]} \\
A x+B y=C|\times E| A E x+B E y=C E
\end{gathered}
$$

Untuk menemukan nilai $x$ dan $y$, dilakukan metode eliminiasi dari persamaan rumus sebelumnya.

\subsection{Simulasi Perhitungan Manual}

Simulasi perhitungan manual pada penelitian ini menggunakan metode trilateration dengan contoh menggunakan data pengujian sebagai berikut :

\section{Free Space Path Loss}

Contoh perhitungan nilai log normal shadowing model untuk mencari $\mathrm{d}=4$ meter dari akses poin adalah sebagai berikut :

Nilai $\mathrm{L}=\mathrm{RSSI}=-44 \mathrm{dBm}, n=3, C=-25$.

\section{Akses Poin 1}

$$
\begin{aligned}
& F S P L(d B)=-10(n) \cdot \log _{10}(d)+20 \cdot \log _{10}(f)-C \\
& -44=-10(3) \cdot \log _{10}(d)+20 \cdot \log _{10}(2400) \\
& -(-25)
\end{aligned}
$$

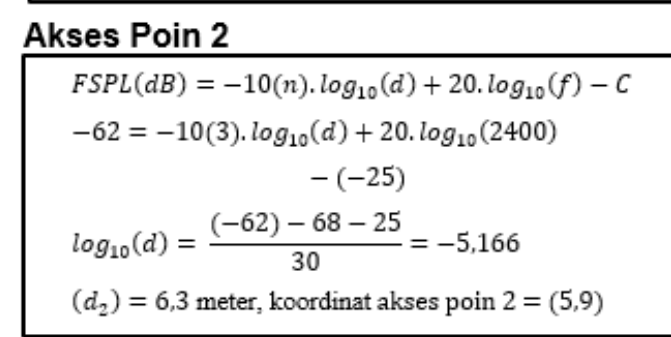

\section{Akses Poin 3}

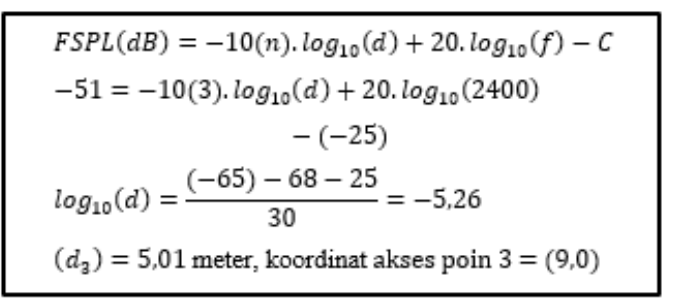

Berdasarkan perhitungan jarak antara akses poin $\left(x_{i}, y_{i}\right)$ dengan member $(x, y)$ didapatkan jarak $d_{1}=3,9$ meter, $d_{2}=6,3$ meter, dan $d_{3}=5,01$ meter.

\section{Trilateration}

Metode trilateration digunakan untuk menentukan lokasi member dalam proses transaksi. Dalam menentukan koordinat lokasi transaksi member pada gerbang tol, trilateration diperlukan untuk mencari nilai koordinat unknown node.

Untuk mencari nilai koordinat member $(x, y)$ maka perlu dilakukan eliminasi dari jarak antara titik akses poin dengan titik member seperti berikut : 
Penyelesaian persamaan akses poin 1:

Penyelesaian persamaan akses poin 3:

$4^{2}=(x-0)^{2}+(y-0)^{2}$
$16=x^{2}+v^{2}$

Penyelesaian persamaan akses poin 2:

$$
\begin{aligned}
& 5^{2}=(x-9)^{2}+(y-0)^{2} \\
& 25=x^{2}-18 x+81+y^{2} \\
& -56=x^{2}-18 x+y^{2}
\end{aligned}
$$

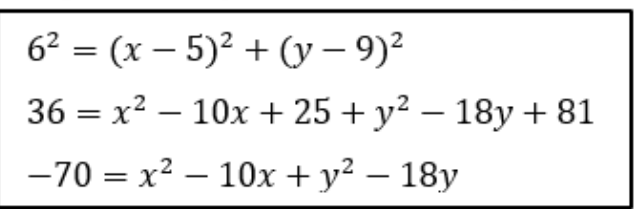

Penyelesaian persamaan koordinat estimasi dengan eliminasi:

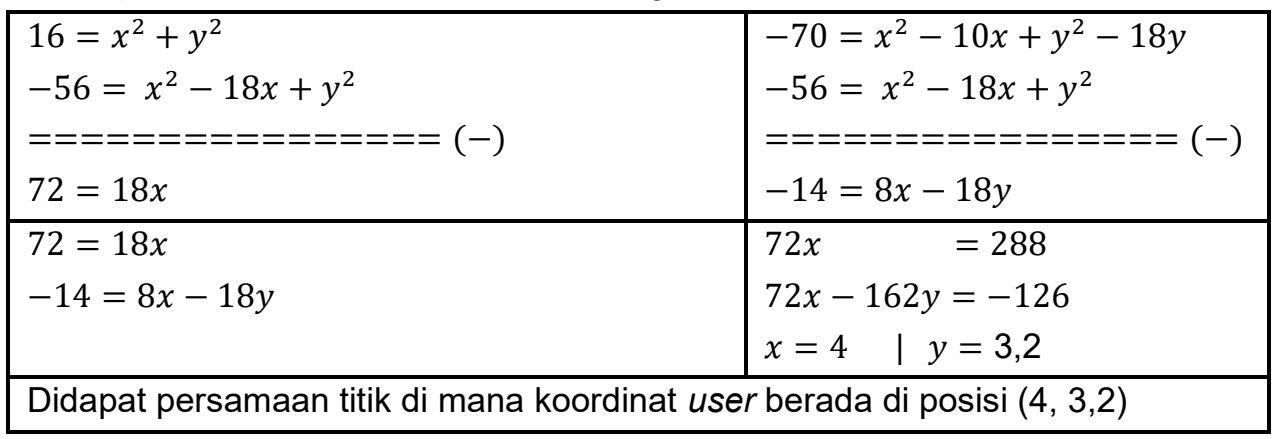

\section{References Point Database}

Pada proses penentuan lokasi transaksi digunakan database. Dimana sistem memiliki database koordinat yang dapat mewakili lokasi gardu transaksi pada tiap gerbang tol. Posisi koordinat pada database terdiri dari 2 koordinat yaitu $x$ dan $y$.

Nilai $x$ mewakili posisi koordinat horizontal member, yang dimana nilai horizontal sebagai penentu posisi gardu transaksi member. Nilai $y$ mewakili posisi koordinat vertikal member, yang dimana nilai vertikal sebagai penentu posisi member dapat melakukan transaksi. Kedua koordinat ini yang mewakili masing-masing posisi member pada gardu transaksi dan waktu transaksi pada

\begin{tabular}{|c|c|c|c|c|c|c|c|c|}
\hline \multirow{2}{*}{ Nama Gardu } & \multicolumn{2}{|c|}{ Koordinat } & \multirow{2}{*}{ Nama Gardu } & \multicolumn{2}{|c|}{ Koordinat } & \multirow{2}{*}{ Nama Gardu } & \multicolumn{2}{|c|}{ Koordinat } \\
\hline & $\mathrm{x}$ & $y$ & & $\mathrm{x}$ & $\mathrm{y}$ & & $x$ & y \\
\hline \multirow{5}{*}{ Gardu tol nomor 1} & 0 & 0 & \multirow{5}{*}{ Gardu tol nomor 4} & 18 & 0 & \multirow{5}{*}{ Gardu tol nomor 7} & 36 & 0 \\
\hline & 1 & 1 & & 19 & 1 & & 37 & 1 \\
\hline & 2 & 2 & & 20 & 2 & & 38 & 2 \\
\hline & 3 & 3 & & 21 & 3 & & 40 & 3 \\
\hline & 4 & 4 & & 22 & 4 & & 41 & 4 \\
\hline \multirow{5}{*}{ Gardu tol nomor 2} & 6 & 0 & \multirow{5}{*}{ Gardu tol nomor 5} & 24 & 0 & \multicolumn{3}{|c|}{ Koordinat } \\
\hline & 7 & 1 & & 25 & 1 & ARSES PUII & $\mathrm{x}$ & y \\
\hline & 8 & 2 & & 26 & 2 & AP 1 & 0 & 0 \\
\hline & 9 & 3 & & 27 & & AP 2 & 5 & 9 \\
\hline & 10 & 4 & & 28 & 4 & AP 2 & 5 & 9 \\
\hline \multirow{5}{*}{ Gardu tol nomor 3} & 12 & 0 & \multirow{5}{*}{ Gardu tol nomor 6} & 30 & 0 & AP 3 & 9 & 0 \\
\hline & 13 & 1 & & 31 & 1 & User & 4 & 3,2 \\
\hline & 14 & 2 & & 32 & 2 & \multirow{3}{*}{\multicolumn{3}{|c|}{ User berada pada Gardu Tol Nomor 1}} \\
\hline & 15 & 3 & & 33 & 3 & & & \\
\hline & 16 & 4 & & 34 & 4 & & & \\
\hline
\end{tabular}
gerbang tol sebagai mana pada tabel berikut.

Tabel 2. Tabel Database Gardu Tol 


\subsection{Tampilan Antar Muka}

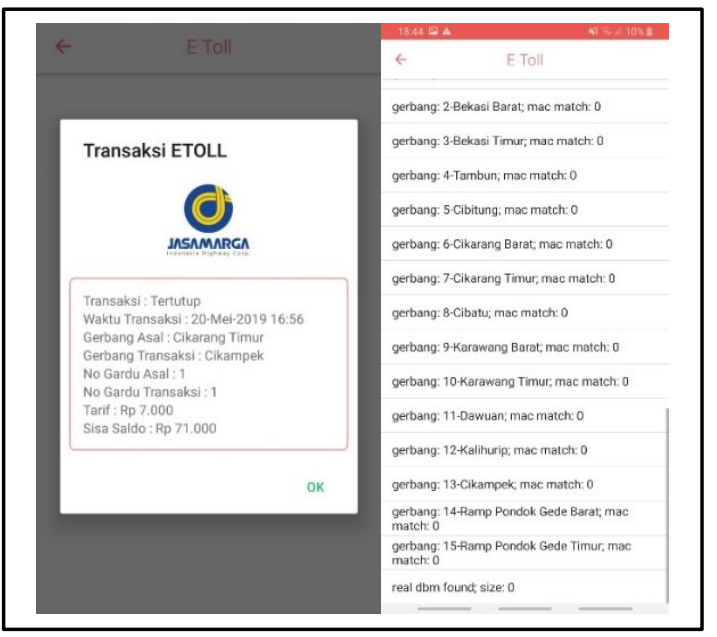

Gambar 13. Halaman Transaksi

\section{KESIMPULAN}

a. Berdasarkan pengujian yang dilakukan dengan menerapkan variabel Pathloss exponent $(n)=3$ dan Environment constant $(c)=-25$, diperoleh hasil akurasi pada sistem dengan nilai rata-rata $92,7 \%$ pada toleransi jarak \pm 1 meter dari jarak sebenarnya.

Tabel 3. Uji Akurasi Koordinat

\begin{tabular}{|c|c|c|c|c|c|c|c|c|c|c|c|c|c|c|c|c|c|}
\hline & \multicolumn{2}{|c|}{ Koordinat Real (m) } & \multicolumn{2}{|c|}{ Koordinat System (m) } & \multicolumn{2}{|c|}{ Selisih (m) } & \multicolumn{2}{|c|}{ Akurasi (\%) } & & \multicolumn{2}{|c|}{ Koordinat Real (m) } & \multicolumn{2}{|c|}{ Koordinat System (m) } & \multicolumn{2}{|c|}{$\begin{array}{l}\text { Selisih }(\mathrm{m}) \\
\end{array}$} & \multicolumn{2}{|c|}{ Akurasi (\%) } \\
\hline & $x$ & $\mathrm{y}$ & $x$ & $\mathrm{y}$ & $x$ & $\mathrm{y}$ & $\begin{array}{ll}x \\
\end{array}$ & $y$ & & $x$ & $y$ & $\mathrm{x}$ & $\mathrm{y}$ & $x$ & $y$ & $x$ & $\mathrm{y}$ \\
\hline \multirow{25}{*}{$\begin{array}{c}\mathrm{G} \\
\mathrm{A} \\
\mathrm{R} \\
\mathrm{D} \\
\mathrm{U}\end{array}$} & 0.00 & 0.00 & 0.23 & 0.18 & 0.23 & 0.18 & 99.77 & 99.82 & & 10.00 & 0.00 & 10.87 & 0.11 & 0.87 & 0.11 & 99.91 & 99.89 \\
\hline & 0.00 & 1.00 & 0.71 & 1.20 & 0.71 & 0.20 & 99.29 & 99.80 & & 10.00 & 1.00 & 10.35 & 1.24 & 0.35 & 0.24 & $\begin{array}{ll}99.97 \\
\end{array}$ & 99.76 \\
\hline & 0.00 & 2.00 & 0.77 & 2.10 & 0.77 & 0.10 & 99.23 & 99.95 & & 10.00 & 2.00 & $\begin{array}{l}10.17 \\
\end{array}$ & 2.91 & 0.17 & 0.91 & 99.98 & 99.54 \\
\hline & 0.00 & 3.00 & 0.83 & 3.20 & 0.83 & 0.20 & 99.17 & 99.93 & & 10.00 & $\begin{array}{l}3.00 \\
\end{array}$ & 10.56 & $\begin{array}{l}3.44 \\
\end{array}$ & 0.56 & 0.44 & $\begin{array}{ll}99.94 \\
99\end{array}$ & 99.85 \\
\hline & 0.00 & 4.00 & 0.89 & 4.16 & 0.89 & 0.16 & 99.11 & 99.96 & & 10.00 & 4.00 & 10.86 & 4.65 & 0.86 & 0.65 & 99.91 & 99.84 \\
\hline & 1.00 & 0.00 & 0.95 & 0.00 & -0.05 & 0.00 & 98.05 & 100.00 & & 10.00 & 0.00 & 10.27 & 0.51 & 0.27 & 0.51 & $\begin{array}{ll}99.97 \\
\end{array}$ & 99.49 \\
\hline & 1.00 & 1.00 & 1.01 & 1.80 & 0.01 & 0.80 & 99.99 & 99.20 & & 11.00 & 1.00 & 11.52 & 1.56 & 0.52 & 0.56 & 99.95 & 99.44 \\
\hline & 1.00 & 2.00 & 1.07 & 2.22 & 0.07 & 0.22 & 99.93 & 99.89 & & 11.00 & 2.00 & 11.47 & 2.29 & 0.47 & 0.29 & 99.96 & 99.86 \\
\hline & 1.00 & 3.00 & 1.13 & 3.26 & 0.13 & 0.26 & 99.87 & 99.91 & & 11.00 & 3.00 & 11.73 & 3.22 & 0.73 & 0.22 & 99.93 & 99.93 \\
\hline & 1.00 & 4.00 & 1.19 & 4.88 & 0.19 & 0.88 & 99.81 & 99.78 & & 11.00 & 4.00 & 11.34 & 4.08 & 0.34 & 0.08 & 99.97 & 99.98 \\
\hline & 2.00 & 0.00 & 2.94 & 0.84 & 0.94 & 0.84 & 99.53 & 99.16 & & 12.00 & 0.00 & 12.92 & 0.79 & 0.92 & 0.79 & 99.92 & 99.21 \\
\hline & 2.00 & 1.00 & 2.55 & 1.13 & 0.55 & 0.13 & 99.73 & 99.87 & & 12.00 & 1.00 & 12.46 & 1.71 & 0.46 & 0.71 & 99.96 & 99.29 \\
\hline & 2.00 & 2.00 & 2.32 & 2.74 & 0.32 & 0.74 & 999.84 & 99.63 & & 12.00 & 2.00 & 12.21 & 2.31 & 0.2 & 0.31 & 99.98 & 99.85 \\
\hline & 2.00 & 3.00 & 2.07 & 3.53 & 0.07 & 0.53 & 99.97 & 99.82 & & 12.00 & 3.00 & 12.58 & 3.12 & 0.58 & 0.12 & 99.95 & 99.96 \\
\hline & 2.00 & 4.00 & 2.86 & 4.56 & 0.86 & 0.56 & 999.57 & 99.86 & & 12.00 & $\begin{array}{l}4.00 \\
\end{array}$ & 12.97 & $\begin{array}{l}4.51 \\
\end{array}$ & 0.97 & 0.51 & 99.92 & 99.87 \\
\hline & 3.00 & 0.00 & 3.02 & 0.58 & 0.02 & 0.58 & 999.99 & 99.42 & & 13.00 & $\begin{array}{l}0.00 \\
\end{array}$ & 13.58 & $\begin{array}{l}0.86 \\
\end{array}$ & 0.58 & 0.86 & 99.96 & 99.14 \\
\hline & 3.00 & 1.00 & 3.05 & 1.85 & 0.05 & 0.85 & 999.98 & 99.15 & & 13.00 & 1.0 & 13.17 & 1.5 & 0.1 & 0.5 & 99.99 & 99.47 \\
\hline & 3.00 & 2.00 & 3.09 & 2.71 & 0.09 & 0.71 & 99.97 & 99.64 & & 13.00 & 2.00 & 13.84 & 2.43 & 0.84 & 0.43 & 99.94 & 99.79 \\
\hline & 3.00 & 3.00 & 3.09 & 3.60 & 0.09 & 0.60 & 999.97 & 99.80 & & 13.00 & $\begin{array}{l}3.00 \\
\end{array}$ & 13.07 & $\begin{array}{l}3.56 \\
\end{array}$ & 0.07 & 0.56 & 99.99 & 99.81 \\
\hline & 3.00 & 4.00 & 3.64 & 4.30 & 0.64 & 0.30 & 999.79 & 99.93 & & $\begin{array}{l}13.00 \\
\end{array}$ & 4.00 & 13.40 & 4.68 & 0.40 & 0.68 & $\begin{array}{l}99.97 \\
\end{array}$ & 99.83 \\
\hline & 4.00 & 0.00 & 4.21 & 0.22 & 0.21 & 0.22 & 99.95 & 99.78 & & $\begin{array}{l}14.00 \\
\end{array}$ & 0.00 & 14.91 & $\begin{array}{l}0.09 \\
\end{array}$ & 0.91 & 0.09 & 99.93 & 99.91 \\
\hline & 4.00 & 1.00 & 4.94 & 1.77 & 0.94 & 0.77 & 99.77 & 99.23 & & 14.00 & 1.00 & 14.15 & 1.79 & 0.15 & 0.79 & 99.99 & 99.21 \\
\hline & $\begin{array}{l}4.00 \\
\end{array}$ & 2.00 & 4.98 & 2.95 & 0.98 & 0.95 & $\begin{array}{l}99.75 \\
\end{array}$ & $\begin{array}{l}99.52 \\
\end{array}$ & & $\begin{array}{l}14.00 \\
\end{array}$ & 2.00 & 14.30 & 2.28 & 0.30 & 0.28 & 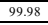 & 99.86 \\
\hline & 4.00 & 3.00 & 4.84 & 3.47 & 0.84 & 0.47 & 999.79 & 99.84 & & $\begin{array}{l}14.00 \\
\end{array}$ & 3.00 & 14.83 & 3.93 & 0.83 & 0.93 & 99.94 & 99.69 \\
\hline & 4.00 & 4.00 & 4.13 & $\begin{array}{l}4.31 \\
\end{array}$ & 0.13 & 0.31 & 999.97 & 99.92 & & 14.00 & 4.00 & 14.98 & 4.60 & 0.98 & 0.60 & 99.93 & 99.85 \\
\hline \multirow{25}{*}{$\begin{array}{l}\text { R } \\
\text { D } \\
\text { U }\end{array}$} & 5.00 & 0.00 & 5.82 & 0.96 & 0.82 & 0.96 & 99.84 & 99.04 & & 15.00 & 0.00 & 15.11 & $\begin{array}{l}0.50 \\
\end{array}$ & 0.11 & 0.50 & $\begin{array}{r}99.99 \\
\end{array}$ & 99.50 \\
\hline & 5.00 & 1.00 & 5.56 & 1.34 & 0.56 & 0.34 & 99.89 & 97.66 & & 15.00 & 1.00 & 15.48 & 1.48 & 0.48 & 0.48 & 99.97 & 99.52 \\
\hline & 5.00 & 2.00 & 5.97 & 2.47 & 0.97 & 0.47 & 99.81 & 95.53 & & 15.00 & 2.00 & 15.87 & 2.39 & 0.87 & 0.39 & 99.94 & 99.81 \\
\hline & 5.00 & 3.00 & 5.78 & 3.68 & 0.78 & 0.68 & 99.84 & 93.32 & & 15.00 & 3.00 & 15.54 & $\begin{array}{l}3.29 \\
\end{array}$ & 0.54 & 0.29 & 99.96 & 99.90 \\
\hline & 5.00 & 4.00 & 5.30 & 4.39 & 0.30 & 0.39 & 99.94 & 91.61 & & 15.00 & 4.00 & 15.74 & 4.75 & 0.74 & 0.75 & \begin{tabular}{|c|}
99.95 \\
\end{tabular} & 99.81 \\
\hline & 6.00 & 0.00 & 6.08 & $\begin{array}{l}0.89 \\
\end{array}$ & 0.08 & 0.89 & 999.99 & 99.11 & & 16.00 & $\begin{array}{l}0.00 \\
\end{array}$ & 16.36 & $\begin{array}{ll}0.21 \\
\end{array}$ & 0.36 & 0.21 & $\begin{array}{l}99.98 \\
\end{array}$ & 99.79 \\
\hline & 6.00 & 1.00 & 6.26 & 1.56 & 0.26 & 0.56 & 99.96 & 97.44 & & 16.00 & 1.00 & 16.00 & 1.20 & 0.00 & 0.20 & 100.00 & 99.80 \\
\hline & 6.00 & 2.00 & 6.22 & 2.71 & 0.22 & 0.71 & 99.96 & 95.29 & & 16.00 & 2.00 & 16.64 & 2.47 & 0.64 & 0.47 & 99.96 & 99.77 \\
\hline & 6.00 & 3.00 & 6.04 & 3.07 & 0.04 & 0.07 & 99.99 & 93.93 & & 16.00 & 3.00 & 16.62 & $\begin{array}{l}3.86 \\
\end{array}$ & 0.62 & 0.86 & $\begin{array}{l}99.96 \\
\end{array}$ & $\begin{array}{l}99.71 \\
\end{array}$ \\
\hline & 6.00 & 4.00 & 6.79 & $\begin{array}{r}4.83 \\
\end{array}$ & 0.79 & 0.83 & $\begin{array}{r}99.87 \\
\end{array}$ & 91.17 & & 16.00 & $\begin{array}{l}.00 \\
\end{array}$ & 16.75 & 4.1 & 0.7 & 0.18 & 99.95 & 99.96 \\
\hline & 6.00 & 0.00 & 6.11 & 0.40 & 0.11 & 0.40 & 99.98 & 99.60 & & $\begin{array}{l}17.00 \\
\end{array}$ & 0.00 & $\begin{array}{l}7.16 \\
\end{array}$ & $\begin{array}{l}0.24 \\
\end{array}$ & 0.16 & 0.24 & \begin{tabular}{|l|}
99.99 \\
\end{tabular} & 99.76 \\
\hline & 7.00 & 1.00 & 7.09 & 1.88 & 0.09 & 0.88 & 99.99 & 97.12 & & $\begin{array}{l}17.00 \\
\end{array}$ & 1.00 & 17.10 & 1.00 & 0.10 & 0.00 & 99.99 & 100.00 \\
\hline & 7.00 & 2.00 & 7.90 & 2.90 & 0.90 & 0.90 & 999.87 & 95.10 & & 17.8 & 2.0 & 17.63 & 2.2 & 0.63 & 0.28 & 99.96 & 99.86 \\
\hline & 7.00 & 3.00 & 7.08 & 3.30 & 0.08 & 0.30 & 999.99 & 93.70 & & $\begin{array}{l}17.00 \\
\end{array}$ & 3.00 & 17.75 & 3.9 & 0.75 & 0.96 & 99.96 & 99.68 \\
\hline & 7.00 & 4.00 & 7.25 & $\begin{array}{l}4.58 \\
\end{array}$ & 0.25 & 0.58 & 999.96 & 91.42 & & $\begin{array}{l}17.00 \\
\end{array}$ & $\begin{array}{l}4.00 \\
\end{array}$ & 17.71 & 4.2 & 0.71 & 0.27 & 99.96 & 99.93 \\
\hline & 7.00 & 0.00 & 7.52 & 0.94 & 0.52 & 0.94 & 99.93 & 99.06 & & 18.00 & 0.00 & 18.89 & 0.61 & 0.89 & 0.61 & 99.95 & $\begin{array}{l}99.39 \\
\end{array}$ \\
\hline & 8.00 & 1.00 & 8.87 & 1.53 & 0.87 & 0.53 & 99.89 & 97.47 & & 18.00 & 1.00 & 18.3 & 1.1 & 0.39 & 0.16 & 99.98 & 99.84 \\
\hline & 8.00 & 2.00 & 8.67 & 2.08 & 0.67 & 0.08 & 99.92 & 95.5 & & \begin{tabular}{|l|l}
18.00 \\
\end{tabular} & 2.00 & 18.77 & 2.83 & 0.77 & 0.83 & 99.96 & 99.59 \\
\hline & 8.00 & 3.00 & 8.40 & 3.47 & 0.40 & 0.47 & 999.95 & 93.53 & & $\begin{array}{l}18.00 \\
\end{array}$ & $\begin{array}{l}3.00 \\
\end{array}$ & 18.27 & $\begin{array}{l}3.44 \\
\end{array}$ & 0.27 & 0.44 & 99.99 & 99.85 \\
\hline & 8.00 & 4.00 & 8.54 & 4.45 & 0.54 & 0.45 & 99.93 & 91.55 & & 18.00 & 4.00 & 18.59 & 4.09 & 0.59 & 0.09 & 99.97 & 99.98 \\
\hline & 9.00 & 0.00 & 9.20 & 0.64 & 0.20 & 0.64 & 99.98 & 99.36 & & $\begin{array}{l}19.00 \\
\end{array}$ & 0.00 & 19.39 & 0.30 & 0.39 & 0.30 & 99.98 & 99.70 \\
\hline & 9.00 & 1.00 & 9.20 & $\begin{array}{l}1.07 \\
\end{array}$ & 0. & 0.07 & 99.98 & 97. & & 19.00 & 1.00 & 19.00 & 1.56 & 0.00 & 0.56 & 100.00 & 99.44 \\
\hline & 9.00 & 2.00 & 9.63 & 2.40 & 0.63 & 0.40 & 999.93 & 95.60 & & $\begin{array}{l}19.00 \\
\end{array}$ & 2.00 & 19.30 & $\begin{array}{l}2.01 \\
\end{array}$ & 0.30 & 0.01 & 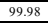 & 1000.00 \\
\hline & 9.00 & 3.00 & 9.37 & 4.00 & 0.37 & 1.00 & 99.96 & 93.00 & & $\begin{array}{l}19.00 \\
\end{array}$ & 3.00 & 19.64 & $\begin{array}{l}3.03 \\
\end{array}$ & 0.64 & 0.03 & 99.97 & 99.99 \\
\hline & 9.00 & 4.00 & 9.06 & 4.96 & 0.06 & 0.96 & 99.99 & 91.04 & & 19.00 & 4.00 & 19.02 & 4.54 & 0.02 & 0.54 & 100.00 & 99.87 \\
\hline
\end{tabular}


b. Hasil response time mendapatkan waktu terbaik pada waktu 1,1 detik dan rata-rata transaksi pada waktu 2 detik. Respon dari waktu proses tersebut dinilai sangat baik untuk melayani sistem pembayaran tol sesuai standar pelayanan minimum perusahaan yaitu kurang dari 4 detik untuk sistem terbuka dan 8 detik untuk sistem tertutup.

Tabel 4. Uji Response Time

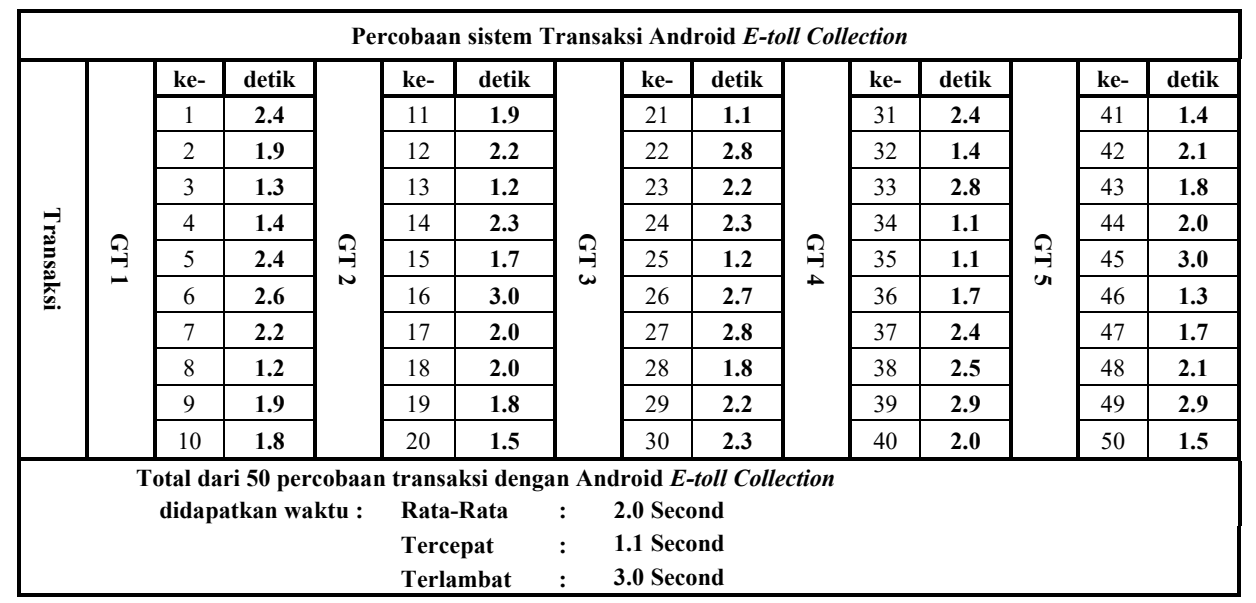

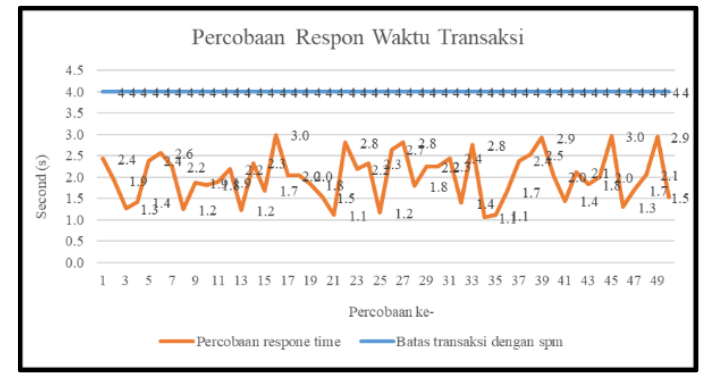

Gambar 14. Uji Coba Respon Waktu Transaksi

c. Tingkat kenyamanan serta keamanan pengguna jalan dinilai baik untuk melakukan transaksi dan pembayaran tol. Hal ini dikarenakan aplikasi memiliki fitur untuk mencegah transaksi ganda pada rekening pengguna jalan dan sistem tapless yang memungkinkan pengguna jalan untuk lebih mudah dalam melakukan transaksi dan pembayaran tol.

d. Fitur pendukung seperti akses info tol, sharing saldo dan top up dinilai cukup membantu. Akses info tol dibutuhkan karena pada setiap gerbang tol belum terdapat layar informasi tol untuk memberikan informasi kepada pengguna jalan. Fitur sharing dan top up saldo bermanfaat bagi pengguna jalan ketika akan melakukan transaksi.

\section{DAFTAR PUSTAKA}

Anwar, B., Jaya, H., \& Kusuma, P. I. (2014). Implementasi Locations Based Service Berbasis Android Untuk Mengetahui Posisi User. Jurnal SAINTIKOM, 13, 121-133.

Badan Pemeriksa Keuangan Republik Indonesia. (2018). Laporan Hasil Pemeriksaan Kinerja Pengelolaan Operasional Jalan Tol Atas Kelancaran Lalu Lintas Dan Kebijakan Tarif Pada 
Kementerian Pekerjaan Umum Dan Perumahan Rakyat, Badan Pengatur Jalan Tol, Dan Badan Usaha Jalan Tol Di Dki Jakarta, Jawa Barat, Jawa.

Dhurat, A., Magal, P., Chheda, M., \& Ingle, D. (2014). Gateless Electronic Toll Collection using RFID, 16(2), 73-80.

Fatkhurrahman, M. A., Syafei, W. A., \& Darjat, D. (2017). Perancangan Prototipe Sistem Gerbang Tol Cerdas Berbasis Rfid Dan Notifikasi Pembayaran Via Social Messenger. Transient, 6(4), 690-697. Retrieved from https://ejournal3.undip.ac.id/index.php/transient/article/view/18887

Jasa Marga. (2018). Data Laporan Perusahaan Lalu Lintas OBU dan NON OBU April 2018. Kupper, A. (2005). Location-based Services Fundamentals and Operation, 5. Retrieved from http://onlinelibrary.wiley.com/doi/10.1002/0470092335.fmatter/pdf\%5Ct\%5Cn

Mistry, H. P., \& Mistry, N. H. (2015). RSSI Based Localization Scheme in Wireless Sensor Networks: A Survey. 2015 Fifth International Conference on Advanced Computing \& Communication Technologies, 647-652.

Schmuller, J. (2004). No Sams Teach Yourself UML in 24 HoursTitle.

Yuliawan, A., Sakti, N., Priyandari, Y., \& Hisjam, M. (2016). Perancangan Sistem Informasi Manajemen Auditor Teknologi pada Sistem Nasional Audit Teknologi ( SNAT ) Menggunakan Metode Grapple, 3-4. 